\title{
A GERMAN PERSPECTIVE ON LEGAL AND POLITICAL PROBLEMS OF COALITION GOVERNMENTS
}

\author{
Ingo von Münch*
}

In September and October 1998 Professor von Münch was a visiting fellow of the New Zealand Institute of Public Law. During an extremely busy visit, Professor von Münch gave a number of seminars on aspects of German Constitutional and Electoral Law. These seminars, given by both a leading Constitutional and Electoral Law academic and a former deputy prime minister of the State of Hamburg and former member of the Bundesrat, or German Senate, were timely given the trials and tribulations of New Zealand's first MMP Coalition Government which had then just ended in the sacking of the minor party's leader as Deputy Prime Minister. In contrast to much of the contemporary gloom at the perceived failed hope of MMP, Professor von Münch presented a hopeful view of both the electoral system that New Zealand had imported from Germany and of the possibilities of Coalition Government. The following is an enlarged text of a speech, delivered to the Public Law section of the New Zealand Ministry of Justice.

\section{INTRODUCTION}

Throughout the world governments formed by a coalition are not seen as a rare exception but, at least in some parts of the world, as the typical political situation. In Europe, Coalition Governments presently govern the vast majority of countries. ${ }^{1}$

In the Pacific, Australia and Japan are prominent examples of countries governed by coalition. New Zealand has had a Coalition Government during the years and a half was terminated only very recently. ${ }^{2}$

* Dr Jur (Frankfurt/Main), Dr Jur hc (Rostock), Emeritus Professor of Constitutional Law and Public International Law, Hamburg, Germany. The author thanks Dr Petra Butler (Ministry of Justice) for organising the meeting and the editor for checking the translation. The responsibility rests with the author.

1 Examples are: Albania, Belgium, Bulgaria, the Czech Republic, Denmark, Finland, France, Hungary, Iceland, Ireland, Italy, Latvia, Lithuania, Luxemburg, The Netherlands, Poland, Romania. 
The European examples were taken from today. Tomorrow, some of these coalition governments might have already broken up. Coalitions are contrary to eternity. In some countries the situation is even unclear. Is Russia being governed by a coalition at present or by some other form of government? We do not know this precisely.

The classic example of a country governed by coalitions for decades is Germany. From the very beginning of the so-called Weimar Republic (the first democratic German State) in 1919 - until shortly before Hitler's seizure of power in 1933, all governments in the Weimar Republic were composed of coalitions. The Federal Republic of Germany ("FRG"), founded in 1949, continues this tradition. All German Federal governments since that time have been, without any exception, formed by coalitions. ${ }^{3}$

The history of the German States (the "Länder") within the Federation has been slightly different. Only about $60 \%$ of the various and numerous States' governments (Landesregierungen) have been coalition governments, and this is still the situation at present. ${ }^{4}$ Summarising, we may say: The Federal Republic of Germany is a Coalition Republic.

Having in mind the great importance of Coalition Governments in history and politics in Germany, we have to observe an astonishing asymmetry between the political importance of this issue on the one side and the absence of legal regulations at the other side. Neither the Constitution of the FRG (the "Grundgesetz" or Basic Law), nor the Federal Electoral Law, nor any law of the individual States, even mention the words "Coalition Government". Among hundred thousands of Court decisions there is only one about legal problems of a Coalition Government ${ }^{5}$ and only rather few publications deal with this topic ${ }^{6}$ although legal problems do exist.

2 The National - New Zealand First colation was de facto terminated August 1998 on the dismissal of the Hon Winston Peters as Deputy Prime Minister and Treasurer. The coalition had governed since December 1997 under a formal coalition agreement.

3 See Ingo von Münch, Rechtliche and politische Probleme von Koalitionsregierungen (Berlin/New York, de Gruyter, 1993) 33 and following.

4 The Federal Republic of Germany consists of 16 States, 10 of which are at present $(1$ December 1998) under the administration of Coalition Governments, 5 under the administration of a OneParty-Government, 1 under the administration of a One Party-Minority-Government.

5 Entscheidungen des Bundesgerichtshofs in Zivilsachen (Decisions of the Federal Civil Court) BGHZ, 29 187. The Court had to decide whether a tape of negotiations for concluding a Coalition Agreement had to be handed over to the partner of the negotiations. The then Federal Chancellor and Leader of the CDU had refused such a handing over, arguing that the tape contained confidential information about foreign affairs.

6 The most important articles are cited by Ingo von Münch, above n 3 and by $\mathrm{R}$ Zuck, "Verfassungswandel durch Vertrag?" [1998] Zeitschrift für Rechtspolitik 457. 


\section{DISTINGUISHING COALITION GOVERNMENTS FROM OTHER FORMS OF GOVERNMENTS}

Discussing legal problems of Coalition Governments we have to clarify, first of all, what the term "coalition" means in this respect. Due to the fact that - at least in the FRG no legal definition of this notion exists, it might be useful to approach the meaning of the term "coalition" from a negative point of view.

(a) No coalition is an alliance of political parties agreed upon before a general election. A coalition can only be formed on the premise that a general election has taken place and that a joint government composed of different political parties - a coalition government - has to be installed.

(b) A Coalition Government is more than a mere support for a government, given by one or more political parties. An example of such a supported government is that of Sweden after the election of the National Parliament ("Riksdag") on 23 September 1998. The then ruling Social-Democratic Party of Prime Minister Persson had won only 36.6 percent of the vote. To continue his government Mr Persson needed the consent of at least two other political parties; he got this support after talks with the Left Party ("Vånstre") and with the Green Party, three days after the election. But Mr Persson had declared immediately after the closing of the polls that he excluded the possibility of a "Coalition Government". Due to this decision, the Left Party and the Greens are not represented in the Swedish Government, but are fighting alongside the Government against the Opposition.

(c) The difference between such support of a Government like that in Sweden on the one hand and a mere toleration of a Government on the other side lies in the fact that a political party which only tolerates the Government does not play an active role in favour of the political activities of the Government, but refrains only from voting in decisive questions against the Government. ${ }^{7}$

(d) Toleration of a Government is a formless process. The tolerating party does not conclude an agreement with the tolerated Government. But imagination and creativity regarding Coalition Governments are boundless: the newest idea in one of the German States has been a so-called "toalition". In Mecklenburg-Vorpommern in Eastern Germany the Government was formed by a coalition of the CDU and the SPD. ${ }^{8}$ Because of personal rivalries between the Prime Minister (a member of the

7 This is the situation in the German State of Sachsen-Anhalt; in this State a One-Party-Minority Government of the SPD is tolerated by the PDS.

8 Abbreviations used for the major German political parties are as follows: CDU: ChristlichDemokratische Union Deutschlands (Conservatives); SPD: Sozialdemokratische Partei Deutschlands (Labour); FDP: Freie Demokratische Partei Deutschlands (Liberals); Die Grünen: 
CDU) and the Deputy Prime Minister (a member of the SPD) and because of tensions between these two political parties, there was a discussion about the political future of governing the State after a possible breaking down of the Coalition Government then in power. The SPD intended to govern the State after the next election with a Minority Government ${ }^{9}$ tolerated by a second political party the PDS (the successor of the former Communist Party). The PDS demanded recognition as an equal partner, and declared that it was not satisfied with the role of a mere tolerating party without any formalisation of this status. Therefore, the idea was born to fix principles and guidelines of the intended toleration in a written agreement. If such an agreement had been concluded between both political parties, the situation would have drawn near to a coalition, without being a coalition in the traditional sense of this word. One might call this connection a "toalition". In fact, at the end of the discussion, the idea was not realised; instead, a "normal" coalition was established between the SPD and the PDS.

(e) Another German political special situation has been created in the City State of Hamburg. The STATT-Partei (which might be translated as "The 'instead of' Party"), which claimed to be an alternative to the other, "established" political parties, agreed after the 1993 election in Hamburg to be a partner of the SPD in the State Government and to fix this partnership in a written agreement. In contrast to the typical procedure of establishing a Coalition Government, the STATT-Partei did not nominate members of the party to serve as ministers for the Government but independent persons. For this reason the STATT-Partei insisted on naming the agreement with the SPD not as a "Coalition Agreement", but a "Co-operation Agreement" ("Kooperationsvertrag"). According to my view, there is neither a legal nor a substantial political difference between such a "Co-operation Agreement" and the traditional "Coalition Agreement".

\section{THE LEGAL NATURE OF COALITION GOVERNMENTS}

German public lawyers are in the midst of an exciting legal problem. Although the FRG, as mentioned above, has been a "Coalition Republic" since 1949, there still exists a controversy in German legal science on the question of the nature of Coalition Agreements. Three different positions are commonly taken in regard to this question:

Bündnis 90/Die Grünen (Greens); PDS: Partei für den demokratischen Sozialismus (Successor of the SED: Sozialistische Einheitspartei Deutschlands - Communists in the former German Democratic Republic commonly referred to East Germany).

9 Minority Governments are a very rare exception in Germany. For the legal problems see K Finkelnburg, Die Minderheitsregierung im deutschen Staatsrecht (de Gruyter, Berlin/New York, 1982). 
(a) Coalition Agreements are not legal instruments but only political settlements. ${ }^{10}$ Coalition Agreements are - according to this position - only "gentlemen's agreements" (which presumes that political parties are gentlemen - a presumption that may raise some doubts).

(b) Coalition Agreements are binding legal instruments like other legal agreements, but are governed by Public Law. ${ }^{11}$

(c) A third view regards Coalition Agreements as non-justiciable legal instruments. In my opinion this is the right view. ${ }^{12}$ The contents of a Coalition Agreement deal, amongst other things, with the composition of a Government, with the aims of the policies of the Government, and with voting in Parliament. All these matters involve Constitutional Law. But, the peculiarity of Coalition Agreements is the fact that these agreements contain imperfect obligations, which are unenforceable in the Courts. Imperfect obligations are not an unknown phenomenon in law, but well-known already in ancient Roman Law as "obligationes naturales". In modern Public International Law the idea of the existence of a so-called "soft-law" is a wide spread idea. ${ }^{13}$ In British Parliamentary practice, there exist "conventions". Different legal agreements may have different legal strength.

\section{WHY OUGHT COALITION AGREEMENTS NOT BE ENFORCED BY COURTS?}

Why are Coalition Agreements not justiciable in the Courts? The answer results from the contrast between the Coalition Agreement "Law" on the one side and Constitutional Law on the other side. This issue may be illustrated by giving three examples:

(a) According to the Constitution of the FRG, the Federal Chancellor ("Bundeskanzler") has the discretion to decide on the composition of his Cabinet; ${ }^{14}$

10 This is the view, amongst others, of K Hesse, Grundzüge des Verfassungsrechts der Bundesrepublik Deutschland (20 ed, C F Müller, Karlsruhe 1995) 79.

11 The Federal Civil Court, above $\mathrm{n} 5$ decided the tape case to be a question of Administrative Law. To my way of thinking this incorrect as Coalition Agreements deal with Constitutional Law.

12 It is noteworthy that the Coalition Agreement of December 1996 between New Zealand First and the New Zealand National Party expressively states this fact under Point 14: "The Parties agree that this agreement shall not be justiciable in the Courts of New Zealand".

13 See for example, P Malanczuk, Akehurst's Modern Introduction to International Law (7 ed, Routledge, London, 1997) 54.

14 This competence is called "Organisationsgewalt" (power to decide about the organisation). See E W Böckenförde, Die Organisationsgewalt der Bundesregierung (2 ed, Duncker \& Hurnblot, Berlin, 1998). 
that is the Chancellor decides how many ministers he or she wants to have in the Cabinet, what competences shall be vested in which ministries, and who shall be nominated to the Federal President, to be appointed by him, as a Federal Minister. ${ }^{15}$ But, the reality of a Coalition Government is that the negotiators of the Coalition Agreement reach terms on the composition of the Cabinet. According to German practice each partner of the Coalition is free to choose the person that that partner wants to sit at the Cabinet table. At the end of the negotiating process the Federal Chancellor has to ratify the decisions of the negotiators of the Coalition Agreement, not as a legal obligation by as a fact

(b) According to the Constitution of the FRG, the Federal Chancellor determines the general guidelines of the Federal Government's policy ("allgemeine Richtlinien der Politik"). ${ }^{16}$ Within the framework set up by these guidelines, each Federal Minister leads his or her ministry independently and on his or her own responsibility. But this regulation in the Constitution is only one side of the coin; the other side is the Coalition Agreement. The modern Coalition is not the small size of the Ten Commandments but that of a telephone directory of a middle town. For instance, the Coalition Agreement between the SPD and the Greens in North-Rhine Westphalia (Germany's largest state), contains 178 tightly printed pages. The Coalition Agreement between the SPD and the Greens establishing the Federal Government in 1998 is shorter, but nevertheless contains a large number of demands all of them together limiting the power of the Federal Chancellor and of the ministers sitting in his cabinet.

(c) The Constitution of the FRG prescribes that the Members of the Federal Parliament (the "Bundestag") shall not be bound by any instructions, but only by conscience. ${ }^{17}$ What about this elementary provision of Parliamentary Law if the Coalition Agreement (as is usually the case) demands that the Members of Parliament who are members of the Coalition Parties have to refrain from crossing the floor?

If there exists a contradiction between the Constitution and the Coalition Agreement how is this problem to be solved? In order to find the answer to this question we have to distinguish the legal sphere of that issue from the political sphere. In the legal sphere,

15 For the powers of the German Head of State see Ingo von Münch, An Example of Republicanism: The German Presidency (1997) 20 UNSWLJ 466.

16 See Article 65(1) of the Basic Law. "The Federal Chancellor shall determine and be responsible for general policy guidelines".

17 See Article 38(1) of the Basic Law. "They (the members of the Bundestag) shall not be bound by any instruction, only by their conscience". 
terms of a Coalition Agreement cannot amend the Constitution. ${ }^{18}$ The rights and powers of the Federal Chancellor, of the Ministers of the Federal Government, and of the Members of the Parliament cannot be shifted or even modified by a Coalition Agreement.

In the political sphere, it is obvious that it is the political interests of the Federal Chancellor and of the Members of his Cabinet and of the Members of Parliament who are representing the parties of the Coalition to follow the policies fixed in the negotiations which have led to the Coalition Agreement. This following does not mean a waiver of competences but the consideration that it is necessary, or at least useful, to keep in line with one's own political party.

The distinction between the legal sphere and the political sphere loses some of its difficulties if we keep in mind that the Coalition Agreement has been negotiated and signed by the top politicians involved. For example, the Coalition Agreement between the CDU and the FDP, which was the political basis of the last Federal Government, had been signed by the then Federal Chancellor Dr Helmut Kohl in his capacity as leader (Chairman) of the CDU, and by the Minister for Foreign Affairs, Dr Klaus Kinkel, as Leader of the FDP. After the spectacular defeat of the Coalition Government of the CDU and the FDP in the General Election of 27 September 1998, the SDP and the Greens established a new government on the basis of a Coalition Agreement of 20 October 1998, which has been signed by, amongst others, the in-coming Federal Chancellor, $\mathrm{Mr}$ Gerhard Schroder, and subsequent Minister for Foreign Affairs, Mr Joschka Fischer. It has to be underlined again that the Coalition Agreement are agreements concluded between political parties ${ }^{19}$ not between state organs and not between parliamentary groups.

\section{POLITICAL PROBLEMS}

As has been mentioned already Coalition Governments are the norm, in the FRG. Everybody is accustomed to this form of government. But this custom does not exclude some criticism of Coalition Governments. The main points in discussion are the following:

(1) The existence of a Coalition Government diminishes the political position of Parliament and of the Government. The political decision making process shifts

18 According to Article 79 of the Basic Law, the Basic Law can be amended only by a law expressly modifying or supplementing its text. Such a law must be carried by two thirds of the Members of the Bundestag (the lower house) and two thirds of the votes of the Bundesrat (the Senate).

19 In the FRG, the Coalition Agreements, after having been negotiated, are proposed to the supreme organ of the Political Party (Congress; General Assembly) for approval. Therefore, the negotiators will not agree terms whose approval by the Political Party might be doubtful. 
from clear procedures to rather informal conversations. In addition, one of the most important principles of a modern Constitution, namely the separation of powers, is circumvented under a Coalition Government.

(2) Under a Coalition Government the political position of the party leaders is strengthened, whereas the position of the Party Organisations is weakened. Only a few members of the political parties involved are members of the Coalition Committees, which are established by the Coalition Agreements, with the task to solving problems, difficulties or disputes between the Coalition Partners. ${ }^{20}$

(3) The sittings of the Coalition Committee are not public. Negotiations in the Committee are, therefore, regarded as a form of secret diplomacy, whereas the principle of democracy demands transparency. The ordinary members of the political parties do not participate in resolving the disputes.

(4) The existence of a Coalition Government requires the politics of compromises. The result of those compromises does not strengthen the Government in power. None of the partners of a Coalition Government is able to push through its own ideas without consent of the Coalition partner.

(5) Due to the compromises, the political responsibility of the Coalition Partners is blurred. Each Coalition partner may say that the other Partner is the brake on the Coalition Government, hindering a good policy to be done by the Government.

(6) The criticism of Coalition Governments culminates in blaming the German type of electoral system which is nearly identical with New Zealand's Mixed-Member Proportional (MMP) electoral system. ${ }^{21}$ The main argument to be heard against the German proportional electoral system is that this electoral system often leads to a relative majority only, ${ }^{22}$ whereas the First-Past-the Post system (FPP) leads to an absolute majority of one Political Party in Parliament.

20 The new German Coalition Government of SPD and Greens has had, initially, some problems of communication between the Coalition Partners. The Coalition Committee, composed of 16 members (eight from each Party) was soon regarded as to be too big. For this reason, an informal "Koalitionsrunde" (a sort of a small round table) has been established; in addition to that, the leaders of the Parliamentary Groups of both Parties have been asked to meet at the beginning of each week for information purposes.

21 The differences between the German and the New Zealand's Electoral System refer only to technical details. For the view in New Zealand see Geoffrey and Matthew Palmer, Bridled Power, New Zealand Government under MMP (3 ed, Oxford University Press, Auckland, 1997).

22 However, in some of the States of the FRG, MMP has led to absolute majorities in the states parliaments, for example, in Bavaria and in Saxonia. 
The dispute about the advantages and the disadvantages of both electoral system with the pro and contra arguments, often seems to be more a creed than a rational reflection. For a politically interested lawyer, criteria to be considered should be: checks and balances; fairness; justice; efficiency.

From all perspectives the proportional electoral system has to be preferred. In this system, checks and balances are anchored already in the Government itself. The necessity to find a compromise is an essential part of democracy. The proportional electoral system guarantees the representation of minorities in Parliament. Worldwide, the proportional electoral system is in advance. In countries, in which this system has not been introduced yet, oppositions demand its introduction. Even in the United Kingdom, which has to be regarded as the strongest fortress of the FPP-electoral system, the British Members of the European Parliament will be elected in 1999 on the basis of the proportional voting system; the same will happen in future with 56 of 129 Members of the Scottish Parliament. The Scottish solution seemed to be indispensable due to the fact that the Tories had not won a single constituency in Scotland in the last General Election; even the Labour Party believed that a Parliament without any opposition would be an institution without sense. The British Electoral Reform Society has been fighting for a change in the British electoral system for decades. ${ }^{23}$ With regard to efficiency, the German experience is that Coalition governments are not less efficient than one-partygovernments. Coalition governments have solved the gigantic political, economic, social and legal problems after 1945 and after the reunification of Germany in 1990.

\section{CONCLUSION}

Despite several disadvantages and problems, Coalition Governments are the best way to govern, in the future, countries with complex societies. A Coalition Government necessarily has to find compromises between the interests of various groups of the society. Life, in general, demands to find compromises every day - why not in political life as well?

23 The commission, which has been established by British Prime Minister Tony Blair, to examine a reform of the electoral system in the United Kingdom, has proposed a modest modification of the FPP Report of the Independent Commission on the Voting System (The Stationery Office, London, 1998). According to my view the proposal of the commission is unsatisfactory. 
